\title{
A KÖZÖSSÉGI MÉDIA HATÁSA A HIP-HOP ÓRÁKRA ÉS TÁNCOSAIRA
}

\author{
Zimányi Gabriella, koreográfus, divattánc tanár, American International School of \\ Budapest
}

Lanszki Anita PhD, egyetemi docens, Magyar Táncmúvészeti Egyetem Pedagógia és Pszichológia Tanszék

\begin{abstract}
Absztrakt
A közösségi média népszerúsége vitathatatlan, felhasználóinak száma a kezdetek óta exponenciálisan nő. Az online jelenlét a múvészetek és ezen belül a hip-hop tánc világát is befolyásolja, mivel a tartalommegosztó platformokon a hip-hop felvételek hirtelen tömegeket értek el. Koreográfusok és táncosok ismert celebekké váltak megosztott táncos videóik nyomán, amelyeken a táncrészletek egyre előadásszerúbbé, szerkesztettebbé, ezáltal manipuláltabbá váltak. A megosztások irreális elvárások elé állítják a tanítani és tanulni vágyókat egyaránt, ezen kívül a közösségimédia-használat számos egyéb jellegzetessége is befolyásolhatja a hip-hop tánc tanítását. A közösségi média hip-hop tánccal való összefüggését kvalitatív mélyinterjúk formájában vizsgáltuk Budapesten, Londonban és Los Angelesben. A megkérdezett koreográfus-tanárok ( $\mathrm{n}=6)$ válaszai alapján sikerült feltárni, milyen negatív és pozitív hatásokat fejt ki a közösségi media a hip-hop oktatására, közelebbről pedig a tanóraszervezésre, valamint a pedagógusok és növendékeik motivációjára. A tanulmányban összegezzük továbbá azt is, hogyan befolyásolják a közösségi médiában található hip-hop tartalmak a koreográfusok és tánciskoláik népszerúségét, a növendékek szakmai fejlődését és munkalehetőségeit az egyes régiókban.
\end{abstract}

Kulcsszavak: közösségi média, hip-hop, motiváció

\section{BEVEZETÉS}

A közösségi média életünk tagadhatatlan részévé vált. Különböző alkalmazásai az információ azonnali, valós idejú megosztását és elérhetőségét szolgálják (Hudson, 2020). Az első, nyilvánosság számára létrehozott közösségi oldal, az 1997-ben a SixDegrees. com elnevezésû́ platform volt (Boyd \& Ellyson, 2007). A legnépszerúbb közösségimédia-alkalmazást, a Facebookot 2004-ben hozta létre Mark Zuckerberg, ezt követte a YouTube, a Twitter és az Instagram (Ahmad, 2018). A Facebook-ot, közel 1,734 milliárdan használják napi szinten a világon a cég 2020 első negyedévi jelentése alapján. ${ }^{1}$ Második helyen a YouTube áll, az Instagram pedig hatodik a sorban (Clement, 2020).

${ }^{1}$ https: / / edge.media-server.com/mmc/p/fx4dahch 


\section{Zimányi Gabriella | Lanszki Anita}

A közösségi médiában megosztott hip-hop videók eleinte az Egyesült Államokban, majd világszerte kisebbségi vagy szubkultúra csoportok öndefiníciójának és közösségépítésének fontos eszközei. A fiatal alkotók saját hip-hop videóikkal részvételi alkotóközösséget hoznak létre, a közösségi média platformjain a hip-hop-ot társadalmi véleménynyilvánításra használják, sajátos öltözködésükkel, mozdulataikkal pedig civil mozgalmat és közösségi identitást építenek ki (Porfilio, Gardner \& Roychoudhury, 2013; Delgado, 2018).

A hip-hop egy reflektív múfaj, a jellegzetes battle (=verseny) motívum is egyfajta dialogikus, egymásra reagáló, kollaboratív versengés a táncosok közt (Hill \& Petchauer, 2012), melynek ideális közvetítője a közösségi média, amely lehetôvé teszi a saját tartalmakon keresztüli önmegjelenítést és az egymás táncvideóira adott reflexiók megosztását. Ez mutatkozik meg a 2018 óta népszerú dance challenge-ekben (=táncos kihívásokban) is. A leghíresebb a Drake In My Feelings kihívása volt. Miután az előadó albuma megjelent, a közösségi médián híres komikus, Shiggy, közzétett egy videót az Instagram oldalán, amint táncol az In My Feelings címú Drake dalra. A videó alá a DoTheShiggy hashtag került, ezzel is bíztatva a követőket a videó ${ }^{2}$ utánzására (Amiftos, 2018).

A versengés motívuma megjelenik a hip-hop videók egy jellegzetes alcsoportjában, a select group videókban is. Ezeken a felvételeken a tanár által kiválasztott növendékek táncolnak kis csoportban vagy szólóban a táncteremben, míg a többi tanuló nézi őket. Ezek a videók elsősorban a tánciskolák, tanárok és táncosok népszerúsítését szolgálják, ezért természetes szempont az elkészítésük során, a tökéletességre törekvés mind tánc-, mind filmtechnikai értelemben. A 2009-ben készült Kennis Class videó ${ }^{3}$ még egy kézikamerás stílusban felvett tanóra végi videó, de fordulópontot hozott a szakmában csak WilldaBeast-ként emlegetett amerikai Will Adams Beyoncé Upgrade U címú dalára készített koreográfiája ${ }^{4}$. Az órai videót több mint 114 millióan nézték meg a YouTube-on. Ez jelenleg 14 millióval több, mint az énekes hivatalos videoklipjének megtekintése. Will videója teljesen elütött az azelőtt készült órai hip-hop videóktól. $\mathrm{Az}$ amerikai táncos és koreográfus Brian Friedman szerint a videó sikere több részletben rejlett. Will csak a select táncosokat, azaz az órán legjobbnak bizonyuló táncosokat filmezte, majd vágta össze egy videóban. Világos volt a termekben, ezért minden jól látható, és a felvétel is jobb minőségû a legtöbb addig készült órai videónál (Burke, 2017). A 2013-ban készült tánciskolai felvételen már filmnyelvi kifejezőeszközöket is találunk, úgy mint stáblista, vágások, fekete-fehér és színes képek váltakozása, plánok használata. A 2018-ban megosztott FEFE Dance - Delaney Glazer videó ${ }^{\text {felépí- }}$ tése hasonló, a kiegészítő elemnek tekinthető, hogy a felvétel bevezetővel kezdődik: a tánciskola először kívülről látható, majd a folyosókon keresztül bejutunk a tömött

\footnotetext{
${ }^{2}$ Stiff Lauren (n.d.). The Shiggy Show - In My Feelings Challenge - Do The Shiggy. YouTube. https:/ / www.youtube.com/watch?v=69LjA8NuEsw

${ }^{3}$ Joe Ryan Show (2009, February 14). Kennis Class: Ciara „Walk on the Wall”. YouTube. https:/ /www. youtube.com / watch? $\mathrm{v}=\mathrm{mjj}$ xVlaYe3c

${ }^{4}$ WilldaBeast Adams (2013, February 18). WilldaBeast Adams, Beyonce: Upgrade U I Learn Tutorial on immaDance.TV. YouTube. https: / / www.youtube.com/watch?v=d3y17D_K9Zw

${ }^{5}$ KreativMndz (2018, November 6). FEFE Dance - Delaney Glazer Choreography I 6ix9ine, Nicki Minaj, Murda Beatz I @deeglazer x\#kmda. YouTube.https: / / www.youtube.com/watch?v=ii_7BjfjLUQ\&list=RDii_7BjfjLUQ\&start_radio $=1 \& \mathrm{t}=0$
} 


\section{Zimányi Gabriella | Lanszki Anita}

táncterembe. A néző a rövid, professzionálisan elkészített felvezetô után tekintheti meg a select group videókat. A filmtechikai újdonságok alkalmazása, a felvételek minőségi javítása befogadhatóbbá teszi ezeket select group videókat. A 2013-as és 2018-as videókhoz fúzött megjegyzésekből kiderül, hogy a számos megtekintés oka az, hogy a nézők maguk is szeretnék megtanulni a koreográfiát és/vagy sztárolják a benne szereplő táncosok valamelyikét. Táncosok és koreográfusok ismert celebekké válhatnak a megosztott videók nyomán, így nem meglepő, hogy a feltöltött táncrészletek is egyre előadásszerúbbé és szerkesztettebbé váltak (Hawgood, 2016).

A videókban látható formai (=filmnyelvi) és tartalmi (=tánctechnikai) tökéletességre való törekvés jegyében csak a legjobb tanulók vehetnek részt a select group táncokban. Ez egyrészt eredményezheti a hip-hop technikák rapid fejlődését és széleskörû népszerúsítését, azonban okozhat egyfajta frusztrációt is a hip-hopot oktató és tanuló közösségekben. Fuhrer (2017) és Laos (2019) szerint ezek a videók inkább promóciós tartalmak, és félrevezető képet mutatnak a tánctanulás világáról. Laos divattáncosokat, koreográfusokat, tánctanárokat valamint egy ügynökséget $(n=5)$ kérdezett meg arról, hogyan változtatta meg karrierjüket a közösségimédia-, azon belül is az Instagram-használat. Az interjúkból kiderült, hogy a közösségi média használata a táncosok önmegjelenítése, önmenedzselése, ezáltal a karrierépítés szempontjából szükségszerûvé és elvárttá vált USÁ-ban a 2010-es évek második felétől, a közösségimédia-profilok egyfajta online portfólióként is szolgálnak (Laos, 2019).

De míg Laos (2019) kutatásának fókuszában elsősorban a közösségi média online marketingben és táncos karrierben játszott szerepére fókuszált, addig jelen kutatásunkban arra voltunk kíváncsiak, hogy a közösségi médiafelületeken népszerú hiphop tartalmak milyen minőségbeli változást okoznak a múfaj oktatásában az Egyesült Királyságban, az USÁ-ban és Magyarországon.

\section{A KUTATÁS MINTÁJA ÉS MÓDSZEREI}

A közösségimédia-használat hatásait a hip-hop táncos közösségre és a hip-hop oktatására kvalitatív vizsgálat formájában térképeztük fel 2018 telén és 2019 tavaszán. A mélyinterjúkra olyan, a szakmájukban elismert hip-hop tanárokat $(n=6)$ kértünk fel, akik nagy létszámban tanítanak táncosokat, és már a közösségi média megjelenése előtt is tanárok voltak.

Börczi Barbara egy budapesti tánciskola alapítója, vezetôje és koreográfusa, és tizenhárom éve tanít a fôvárosban. Csapatai számos hazai versenyen értek el első helyezést, így több tucat kupa és aranyérem tulajdonosa. Nemcsak itthon, hanem külföldön is számos rangos versenyen szerepeltek formációi, például a 2018-ban Varsóban megrendezett World of Dance-en is. Barbara koreografált már koncertet, videoklipet és a 2015-ös X-Faktorban is társkoreográfusként múködött közre. A belvárosi szórakozóhely, az Ötkert, teljes rendezvénysorozatot épített az iskolájára.

Bőhm Attila a világszerte jegyzett budapesti R3D ONE táncstúdió táncosa és tanára. Amerikában Movement Lifestyle ösztöndíjat kapott, és így Los Angelesbe utazhatott, hogy a szakmában kiemelkedő észak-hollywoodi táncstúdióban tanulhasson (themovementlifestyle.com). Az egész világon tart kurzusokat, emellett versenycsapatokat is edz, illetve tánciskoláknak is koreografál.

Hefler Dániel hip-hop tanár és táncos. 2016-ban csapatával, a Side Effect-tel, a Hip 


\section{Zimányi Gabriella | Lanszki Anita}

Hop Unite World Championships-en első helyezést ért el. A 2018-as varsói WOD után a World of Dance Polska tévés músorban szerepelt és koreografált csapatuknak, Börczi Barbarával közösen. Táncosként a Wonderland Show Company és a Freelusion produkcióiban is fellépett.

A HomeBros táncos duó tagjai Unkle TC (George) és Kurtyswift (Kurtis) ghánai táncosok, koreográfusok és tanárok, akik Londonban születtek és jelenleg is az angol fővárosban élnek. 14 éve kezdtek professzionális szinten táncolni a BoyBlue Entertainment hip-hop társulatban. 16 évesen már tanításra is lehetôséget kaptak a társulaton belül, így lassan 10 éve tanítanak Londonban. A HomeBros az afrobeats táncmozgalom angol úttörője. Számos nemzetközi előadóval, a BBC-vel és az Adidas-szal is dolgoztak már együtt. Felléptek a 2012-es olimpiai játékok nyitoüunnepségén, a 2015-ös brit X-Factor fináléján, a Breakin' Convention-ön, az Alan Carr televíziós músorban és számos egyéb előadáson. A Pied Paper címú BoyBlue Entertainment-es előadásuk Laurence Olivier Díjat nyert.

Nika Kljun szlovén táncos, koreográfus és influencer, a los angeles-i Millenium Dance Complex tanára. Táncolt Beyoncé, Jennifer Lopez, Justin Bieber és Ne-Yo mellett, fellépett a világhírú MTV Video Music Awards-on és a Billboard Music Awards-on is. Szerepelt az America's Got Talent, a Dancing with the Stars és az amerikai X-Factor tévés mûsorokban. Koreografált Britney Spears koncertet, és hozzá füződik a 2018-as FIFA Világbajnokság záróünnepélyének megkoreografálása is.

A 24 elemből álló, magyar és angol nyelvû kérdéssor a kutatási kérdések mentén az alábbi területekre fókuszált:

- Milyen alkalmazásokat használnak az egyes országokban a hip-hop táncos közösségekben?

- Milyen előnyökkel és hátrányokkal jár a közösségimédia-használat az oktatók és a növendékek szempontjából?

- Hogyan hatnak a videók a tanórák céljára és tartalmára?

- Hogyan befolyásolja a közösségi média a táncosok munkalehetőségeit és szponzorációját?

Hipotézisünk szerint a közösségi média a hip-hop tanárokra és a diákokra, a tanóratervezésre, a motivációra, a szponzorálásra és a munkalehetőségekre mind hatással van. Előfeltevésünk szerint a pozitív és negatív hatások valószínúleg Los Angelesben a legjelentősebbek, közepes mértékben Londonban és legkevésbé Budapesten kevésbé érezhető a közösségi média hatása. Hipotéziseink között szerepelt, hogy az amerikai és angol adatok kevésben fognak eltérni egymástól, mivel mindkettő nyugati ország, azonos anyanyelvvel és részben közös táncos populációval. A magyarországi hip-hop közösséghez nehezebben és lassabban juthat el bármilyen változás az ország elhelyezkedése, gazdasági helyzete és nem angol anyanyelve miatt.

\section{EREDMÉNYEK}

\subsection{A közösségimédia-használat jellemzői a három ország hip-hop táncos közös- ségeiben}

A hip-hop tánc világában Amerikában tûnt fel először a közösségi média használata, de a jelenség gyorsan nemzetközivé vált. A 2005-ben alapított, videómegosztó You- 


\section{Zimányi Gabriella | Lanszki Anita}

Tube Kljun szerint csak 2007-ben jelent meg a kinti táncosok körében. A hip-hop táncos közösségi média használat a magyar oktatók szerint az amerikaihoz képest csak pár év elteltével jelent meg az országban. Amerikához hasonlóan Magyarországon is kezdetben minden táncos a YouTube-ra töltötte fel a videóit. Egy idő után azonban a YouTube, szerzői jogokra hivatkozva, egyre több videó zenéjét tiltotta le. Bőhm szerint egy táncos számára ez olyan „mintha elvennéd a teniszező kezéből az ütőjét”. Zene nélkül mit sem értek a videók, ezért új platformra lett szükség. Ideiglenesen a Facebook váltotta le a YouTube-ot, de ott elsősorban csak az ismerősök láthatták a feltöltött videókat, illetve a zenék használati szabályozásával is újra kezdődtek a problémák. Böhm elmondása szerint zenei jogsértésre hívatkozva a R3D ONE budapesti tánciskolát körülbelül ötszázezres követettségnél törölte a Facebook az oldalról. Ez hatalmas veszteség volt az iskolának, hiszen több éves munka volt az oldaluk felépítése és az érdeklődők összegyújtése mögött.

$\mathrm{Az}$ interjúalanyok szerint napjainkban a legnépszerúbb platform a hip-hop táncosok körében mindhárom országban az Instagram. Kljun és a HomeBros szerint Amerikában és Angliában is 2014-től kezdtek inkább az Instagram felületén terjedni a táncos videók. Két évvel késóbb a magyar táncosoknál is ez a tendencia mutatkozott. A felületek közötti váltás hátterében a zenék szerzői jogi problémáján kívül más okok is álltak. A hip-hop táncosok legmeghatározóbb csoportja, a tizennégy és harminc év közötti korosztály, egyre több időt kezdett az Instagramon tölteni (Pew Research Center). Ezen kívül az Instagram a többi alkalmazásnál felhasználóbarátabbnak bizonyult (Smith, 2018). A HomeBros szerint „(...) mindenki, aki hírnevet vagy egyik napról a másikra felépített ismertséget szeretne, itt köt ki". Instagramon a felhasználók azokat a személyeket követik, akikre felnéznek és kíváncsiak, ellenben más alkalmazásokkal, ahol az ismerősöket jelölik vissza a felhasználók.

Magyarországon az Instagram mellett a Facebook még mindig elengedhetetlen médiuma a hip-hop óráknak. Az adatlapon információkat, plakátokat és eseményeket lehet megosztani, valamint borítóképeket lehet cserélni, ami a felhasználó teljes ismerősi köréhez eljut. A reklámozás lehetősége mellett a Facebook a csoportkommunikáció médiuma is. A YouTube és az Instagram nem teszi lehetôvé a hasonló rendszerú csoportok létrehozását, ahol több formátumú tartalmat és fórumbeszélgetést is lehet folytatni. Börczi szerint a Facebook megjelenése előtt „,ha lebetegedtél, akkor sms-eket kellett küldeni... rengeteg pénzbe került és mindemellett nem is ment olyan gyorsan az információ".

A tanároknak lépést kell tartaniuk a platformokon képek és videók megosztásával, hogy jelenlétükkel online követőkhöz és a követők által potenciális tanítványokhoz érjen el munkásságuk. Bőhm szerint az online népszerúség meghatározza az órák látogatottságát, ezért egy bizonyos fokig mindenki, aki széles körben akar táncosokat tanítani, egyben népszerúséget is szeretne. Hefler szerint ô maga kevesebb tartalmat osztana meg, ha nem lenne a munkájának fontos eleme a láthatóság.

A londoni HomeBros és a Los Angelesben élő Kljun is a közösségi médiának csak pozitív hatását érezte karrierjén. A két interjúban mindhárom tanár inkább eszközként emlegette a közösségi médiát, mintsem szükségletként, és a tanári pályájuk segítójeként használják a platformokat. 


\subsection{A közösségimédia-használat előnyei és hátrányai a hip-hop oktatásban}

\subsubsection{Tanárok}

A közösségi média egyik előnye az azonos érdeklődésû személyek kapcsolatépítési lehetősége. A HomeBros szerint a fotókban és videókban gazdag online táncos profilok tulajdonosai a világ bármely részérôl megismerkedhetnek, és egymás munkájához közelebb kerülhetnek a közösségi média által. Nika Kljun is számos hozzá hasonló tanárral és táncossal érintkezik a hálón. Bőhm Attila is ezt tapasztalta Magyarországon. Több országban is taníthatott már, annak ellenére, hogy hazája a hiphop világában a kevésbé jelentősebb országokhoz tartozik. Ám nemcsak szakmabeliekkel, hanem énekesekkel, egyéb előadókkal vagy akár cégekkel is összeköttetésbe kerülhetnek a táncosok. Az összes interjúalany úgy vélte, hogy az online láthatóság és az ebből származó kapcsolatok a világ minden pontján megnövelték a tanárok lehetőségeit.

A közösségi média a külföldön élő táncosok munkájának követhetőségét is lehetővé tette. Hefler szerint a magyarországi hip-hop-osoknak lehetősége van külföldi táncosok életének és munkásságának állandó figyelemmel kísérésére. Bőhm szerint az online tartalmak útmutatóként is szolgálnak az itthoniaknak, akik így követhetik, hogy merre halad tovább a stílus, milyen versenyek vannak. Bőhm táncosokkal, koreográfusokkal készült interjúkat is követ, amire 5-10 évvel ezelőtt nem volt mód. Hefler szerint az egészen személyes jellegú információkon túl inspirálódásra is használható a világ táncosainak figyelemmel kísérése. Szerinte az így szerzett ihlet a mozdulatvilágra, a hip-hop táncosoknál előtérbe helyezett öltözködésre, de akár az életvitelre is hat. Bôhm számára a táncos lét sokáig a táncteremre korlátozódott. Amikor egyik példaképe, Keone Madrid bekerült egy televíziós músorba, akkor az amerikai táncos fél évig TRX és CrossFit órákat vett, hogy a teste felkészüljön arra a teherbírásra, ami a táncteremben várta. Bőhm Attilában ekkor tudatosult, hogy a professzionális hip-hop táncos edzése mennyivel sokrétúbb, mint a tánctermi gyakorlás, és ő is többet kezdett edzeni ennek hatására. A külföldi táncosok közelsége lehetőséget ad a szakma legjobbjaitól való tudás elsajátítására is. Börczi szerint a videókból lehet tanulni, ami gyors fejlődést eredményezhet. Vannak kifejezett tutorial (tanító) videók, amelyeket bárki megnézhet és végigcsinálhat ingyen, a világ bármely pontjáról. A külföldi táncosok közelsége az inspirálódás és fejlődés mellett Hefler Dániel számára megnyugtató érzést is ad.

A közösségi média előnyeihez tartozik a személyes motiváció is, amit részben az online platformok biztosítanak a magyar tanárok elmondása szerint. Bôhm úgy gondolja, hogy nemcsak más táncosok videói, hanem a tanárok saját megosztásai is lehetnek motiváció eszközei. Egy videó a széleskörû nézettsége miatt sok emberhez eljuthat, akik pozitív visszajelzéssel is illethetik a tartalmat. Börczi Barbara úgy érzi, élőben ritka a pozitív visszajelzés, de a közösségi média platformjain gyakrabban írnak dicsérô szavakat az emberek.

A legkiemelkedőbb előnye a közösségi médiának, amit mindhárom magyar tanár megemlített, az a felületen való reklámozás, azaz a láthatóság lehetôsége volt. Hefler óráin sokszor a diákok is videóznak, és az így megosztott órai videók nagyon széles körhöz eljutnak, ami reklámozási lehetőséget biztosít a stúdiónak 


\section{Zimányi Gabriella | Lanszki Anita}

és a tanárnak is. Börczi úgy véli, a videómegosztás segíti a diákok szélesebb körû ismertségének elérését is.

Számos előnye mellett a közösségi média hátráltatja is a hip-hop tanárok munkásságát (1. táblázat).

\begin{tabular}{cc}
\hline Elónyök & Hátrányok \\
\hline kapcsolatépítés & aránytalan elvárások \\
külföldi táncosok elérése & trendek kötelező követése \\
szakmai motiváció & népszerúség hajszolása \\
reklámozás & hamis értékrend \\
& felgyorsult munkatempó \\
& érzelmi nyomás \\
\hline
\end{tabular}

1.táblázat: A közösségi média pozitív és negatív hatásai a tanárokra

Az online platformok megjelenése óta a táncosok betekintést nyerhetnek a külföldi táncórákba, ezáltal elvárásokkal érkeznek a saját stúdióikba. Mivel az órákért fizetnek, a diákok válogatnak az iskolák szolgáltatásai között. Ha a stúdió nem biztosítja a táncosok kívánságait, akkor a diákok máshol folytatják a képzésüket. A trendeknek ez a fajta követése egyfajta nyomást gyakorol a tanárokra és az iskolákra (Howard, 2018). Börczi szerint is muszáj a tánctanároknak idomulniuk az elvárásokhoz, különben úgy tûnhet, hogy az adott tanár „őskövület” a trendek által uralt hiphop világában. A HomeBros szerint Angliában is sok tanár teljesen megváltoztatta a tanítási stílusát, hogy az új igényeket kielégítsék az óráik úgy a stúdiókban, mint a workshopokon.

A közösségi média hátránya a trendek megszabása is, ami a hip-hop tanárok tudása helyett a külsőségekre helyezi a hangsúlyt. A magyarországi hip-hop közösség nagyon sokat ad a külföldi táncosok által követett trendekre, ami öltözködésben, beszédstílusban vagy tipikus képek készítésében is meglátszik. A tanárok kinézetének napjainkban nagy jelentősége van, és gyakori, hogy még az órán átadott tudásnál is fontosabbak. Börczi szerint nőként „,...) ha nem vagy szexbomba, akkor eszméletlen nehéz érvényesülnöd". Ám a külsőn kívül a mozdulatoknak is van egyfajta trendjük, amelyek részben meghatározzák a koreográfiákat. Elhíresedett mozdulatok, mint például a dab a közösségi médiában váltak híressé. Sok esetben ezek a mozdulatok nem is professzionális táncosoktól, hanem utcagyerekektől származnak. A mozdulatok kivezetettségének vagy a koreográfiák kezdő lépéseinek is vannak változó trendjei. Börczi szerint a közösségi médián olvasott beszédstílus vagy szóhasználat is gyorsan terjed a közösségen belül, sőt még a zenéket is befolyásolják a trendek. A HomeBros szerint vannak tipikus toplistás zenék, amelyekre mindenki koreografál, majd mindenki ugyanolyan videókat készít rá.

Hátránya a közösségi médiának továbbá, hogy a hip-hop tanárok népszerúségért küzdenek a platformokon, és ezáltal hamis célok elé állítják magukat. A HomeBros szerint a tanárok több figyelmet, követôt és saját brand-et akarnak kialakítani nem- 


\section{Zimányi Gabriella | Lanszki Anita}

csak Amerikában és Angliában, hanem egész Európában is. Bőhm szerint a táncórai videók feltöltésének fő célja nem a diákokkal való büszkélkedés vagy a folyamat bemutatása, hanem a remény, hogy a felvételt majd sokan megnézik. Hefler szerint ebből kifolyólag sok tanár csak a kiválóságai táncát osztja meg a közösségi médián.

A közösségi média hamis értékrendje nemcsak a népszerûségért való versengést, hanem a koreográfiák készítését is befolyásolja. Bőhm úgy véli, magasabb a nézettsége a népszerú slágerekre készült koreográfiáknak, és ez a tanárokat elbizonytalaníthatja és befolyásolhatja bizonyos koreográfiák készítésére és mások elhagyására. Bőhm szerint ugyan nehéz elvonatkoztatni a számoktól, azonban minden tanárnak tudnia kellene, hogy „(...) attól, hogy valamit nem egy millióan néztek meg, az attól még érték”.

Hefler szerint a közösségi platformok megjelenése felpörgetett munkatempót eredményezett a szakmában. Ugyanígy gondolta Bőhm is, aki szerint a tanároknak az új zenék megjelenésének másnapján már koreografálnia kell, az azt követő napokban pedig be kell tanítani és fel kell venni a táncot, mert egy vagy két hét elteltével már több száz másik koreográfia is megjelenik.

A közösségi média ugyanakkor érzelmi nyomást is helyez a hip-hop tanárokra. Börczi szerint a tanárok így jobban szembesülnek vele, hogy ki szereti, és ki nézi le a munkájukat. Szerinte a tánctanároknak (de akár tanítványaiknak is) olyan pszichológusra lenne szükségük, akik egyben sport- és közösségimédia-szakértők, hogy átsegíthessék őket a megélt traumákon. Börczi szerint a külvilág értékeli a koreográfiákat, és sok a negatív hozzászólalás is. Ellenben, ha valaki jelen akar lenni a szakmában, akkor kénytelen ennek kitenni magát, és fennmaradni a platformokon.

\subsubsection{Növendékek}

Az amerikai és angol tanárok a közösségi média előnyei közt említették a diákok táncos karrierjének segítését. A szakma legnépszerúbbjei között vannak azok a tanítványok, akik több millió nézőhöz jutottak el az órai felvételeken keresztül. Kljun úgy gondolja, hogy a videózás „(...) nagyszerű eszköz lehet annak a táncosnak, akit szeret a kamera és a közösségi média”. Bőhm szerint nem kap minden tehetséges táncos ugyanolyan figyelmet ezeken a platformokon, mert az érdeklődés felkeltésének sikeressége sokszor attól is függ, hogy ki mennyire jó médiaszemélyiség. A HomeBros úgy gondolja, hogy ezek a felvételek „olyan embereket vonzanak (legyen az egy énekes, zenei kiadó vagy cég), akik amúgy soha nem látnák az adott táncos tehetségét”. A fiatal sztártáncosok életében a tanítási lehetőség is nagyon korán elérkezik. Nicki Minaj videoklipjéből megismert Taylor Hatala már 13 évesen Los Angelesben és New Yorkban tartott workshopokat (Hurd, 2016). A magyar tanárok szerint a Magyarországon hip-hop-ot tanuló diákoknak nincsenek olyan széles körû lehetőségeik, mint amiket Kljun és a HomeBros is említettek. Viszont az itthoni táncosoknak, a külföldi számokhoz viszonyítva alacsony létszámuk miatt, nagyobb is az esélyük kitûnni a hazai szakmában.

Bőhm és Hefler úgy látja, hogy a diákok követik a külföldön kiemelkedő tehetségú hip-hop táncosokat. A példaképek pedig a külsőségekben és a fejlődésben is befolyásolhatják a diákokat. A közösségimédia-használat nagy előnye Bőhm szerint, hogy a diákok odafigyelnek az étkezésükre, az életmódjukra és a tánc melletti edzésekre is. Heflernek volt olyan tanítványa, aki a példaképével megegyező színúre festette a 


\section{Zimányi Gabriella | Lanszki Anita}

haját, de a nemzetközi videókról koreográfiák betanulása is lehetséges. Hefler véleménye szerint sokan „ahogy nézik, át tudják venni a mozgáskultúrát”, és utána sokkal könnyebben éreznek rá bizonyos stílusokra. Új koreográfiáknál az ilyen diákok egyből azonosulni tudnak a mozdulatvilággal.

Az interjúalanyok mind egyetértettek abban, hogy a közösségi média előnyeihez tartozik a motiváció is, amit a diákok számára biztosítanak a platformok (2. táblázat).

\begin{tabular}{ll}
\hline Elơnyök & Hátrányok \\
\hline táncos karrierépítés & egyéniség elvesztése \\
egészséges életmód & hamis énkép \\
táncos trendek, mozgáskultúra követése & hamis motiváció \\
motiváció & az órák céljának hamis megítélése \\
& rövidebb idejú koncentráció \\
& a megörökítés kényszere \\
\hline
\end{tabular}

2. táblázat: A közösségi média pozitív és negatív hatásai a növendékekre

Magyarországon és Angliában is azt tapasztalták a tanárok, hogy a példaképek kritikátlan követése az egyéni stílus elvesztéséhez vezet - legyen szó öltözködésről vagy a mozdulatokról. Bőhm úgy látja, hogy mindig van felkapottabb ruhadarab vagy márka, amit sok diák visel az órákon. Börczi szerint most éppen a hosszú múköröm vagy a pulcsi betúrése a háton nagy divat, ami a videókon keresztül, Ysabelle Capitulé sztártáncostól indult Los Angelesből. Hefler úgy látja, hogy leginkább azok a táncosok vesznek új ruhákat és figyelnek a kinézetükre, akik többnyire a kiválasztásért hajtanak az órákon. Hefler szerint a videók mindenkire hatnak, de van, akire olyannyira, hogy teljesen lemásolja a teste a videóban látottakat. Börczi szerint nehéz elfogadni, hogy sok diák feláldozza az egyéniségét, és a trendeket másolja. A HomeBros is úgy érzi, hogy a tanítványok szerint az a biztos siker kulcsa, ha a már népszerú táncosokhoz hasonlítanak, ezért „nagyon sok videó pont ugyanúgy néz ki, és a táncosok is ugyanúgy néznek ki (...)." Azok a tanítványok, akik kevésbé követnek influencereket, Hefler szerint éppen ezért sokkal eredetibbek és újszerúbbek maradhatnak, még ha ez nem is mindig előny az Instagram-on.

Az egyéniség elvesztése mellett a közösségi média hátránya a hamis énkép kialakítása a diákokban, ami az önértékelésüket is negatívan befolyásolja. Az Instagram követést, like-olást (a 'tetszik'gomb) és hozzászólást enged a tartalmakhoz. Bőhm szerint a táncban ez lesarkított értékelésre és összehasonlításra ad lehetôséget. Bár nem szabad összetéveszteni a követettséget vagy a nézettséget a tehetséggel, mégis sokaknál ez megtörténik. Börczi is sokszor tapasztalja, hogy a diákok ezért nem tartják magukat semmire. Egy tanfolyamon belül tanuló diákok az azonos koreográfia megosztása után a like-okból kiindulva ítélik meg, hogy ki jobb és rosszabb. 


\section{Zimányi Gabriella | Lanszki Anita}

Bár a nagy számban kedvelt, követett és kommentált tartalmak motiválóak, ugyanakkor hozzájárulhatnak a tanulók hamis motivációjának a kialakulásához. A HomeBros elmondása szerint korábban mindenki azért táncolt, mert mindennél jobban szerette. A barátokkal is az órákon találkoztak, és kamera nélkül valóban megélték az óra pillanatait. Akkor még a társainak akart bizonyítani a táncos és nem a világnak. A HomeBros szerint a mostani 15-20 év közöttiek ezt már lehet, hogy soha nem fogják megélni. A HomeBros szerint ez a fajta, népszerúség hajhászó motiváció a táncos videók szisztematikus manipulálásával is összefügg.

Ezzel összefügg a közösségi média további negatív hatása, miszerint a diákok nem látják a hip-hop órák valódi célját. Kljun szerint a táncórákon való részvételnek a koncentrációról, a technika fejlesztéséről, az edzésről és a táncolni vágyásról kellene szólnia. A HomeBros szerint viszont mivel napjainkban a videózásról szól minden, a diákok nem a fejlődés, hanem az óra végi kiválasztások miatt járnak. Nem a múvészet iránti szeretetük, hanem a figyelemszerzés motiválja őket, mert abban reménykednek, hogy az óravégi felvételek fogják őket is népszerûvé tenni. Szerintük sokakat csak a felvételek elkészítése motivál az órán való részvételre, és annyi időt töltenek a saját profiljuk szerkesztésével, hogy az akár egy részmunkaidős állásnak is megfelelne. A HomeBros úgy látja, hogy a diákok úgy járnak az órákra, mintha előadásra mennének szerepelni, végig markírozzák a teljes tanulási fázist, majd az óra végén, amikor a felvételre kerül sor, akkor „(...) tépi magát mindenki”. Az a céljuk, hogy duóban vagy szólóban is kiállhassanak, és eltáncolhassák a koreográfiát, mert az ilyen videó növelheti a profiljuk nézettségét. Ugyanez a tendencia a híres tanárok óráin is. Minden diák azt reméli, hogy ha bekerülnek egy ilyen tanár videójába akkor a tanár hírességén keresztül, már ők is híresek lesznek. Kljun úgy érzi, hatalmas nyomásnak teszik ki magukat a táncosok az órán való szerepléssel, ami sokaknak a magabiztosságát, de az óra célját biztosan elveszi. A táncórák nem biztonságos, fejlödésre szolgáló terepet, hanem színpadot jelentenek a diákoknak, ami sokakat megfélemlít és gátol a fejlődésben. A HomeBros szerint ez a jelenség mindenhol jelen van, Amerikától kezdve Anglián át teljes Európában már ez lett a jellemző a legtöbb órára.

A HomeBros úgy véli, hogy az emlékezetre és a koncentrációra is negatívan hathat a közösségi média, mert a mai óráknál már nem a hosszú távú fejlesztés a szempont, hanem a koreográfia gyors betanulása majd megosztása. A tanítványok ugyanakkor kevésbé koncentrálnak az órákra, és folyamatos információáramlást igényelnek. Börczi rendszeresen tapasztalja, hogy a mega crew próbákon (nagy létszámú csoportos edzéseken) az éppen nem táncoló diákok egyből a telefonjukat nyomkodják. Börczi úgy látja, hogy amint a kamera megjelenik az órákon, a tanítványok teljes figyelme arra irányul, mert szeretnének jól mutatni a felvételeken. A HomeBros is megemlítette, hogy a diákok a telefonjukkal készített felvételekre figyelnek az órán ahelyett, hogy a fejlődésükkel lennének elfoglalva.

Bőhm szerint nem olyan egyszerû́ a szakma, ahogyan azt az Instagram mutatja. A növendékek csak a táncórákon szembesülnek a valós tudás elérésének nehézségeivel. A táncos pálya sok lemondással jár, nem marad idő, energia és lehetôség egyéb tevékenységek vagy hobbik folytatására, ami Börczi szerint a táncosnak elszomorító érzés lehet. 


\section{Zimányi Gabriella I Lanszki Anita}

\subsubsection{Tanórák}

Az összes tanár a fejlődést vallotta a hip-hop órák legfontosabb céljának, mely meghatározza a tanórák tartalmát is. Börczi fontosnak tartja a folyamatos tréninget és a különböző táncos helyzetek kipróbálását (casting vagy fellépési szituációk). Hefler és Kljun a tudás átadásához elengedhetetlennek tartja az óra jó hangulatát is, ami a feloldódásban és ezáltal a gyors tanulásban segíti a diákokat. Sokan nem tudják magukról hogy tehetségesek, egészen addig, amíg egy jó tanárhoz nem kerülnek, ezért a HomeBros a tanítványok mentorálását is feladatának tartja. Az ô óráiknak célja a kulturális örökség átadása is.

A Magyarországon külön csoportként említett hobby táncosoknál ugyan szintén fontos a fejlődés, de Börczi és Bőhm szerint az ilyen táncosok számára a kikapcsolódás és az óra élvezete az elsődleges. Börczi úgy gondolja, hogy a hobby táncosokban elsôsorban akkor fog elérendő cél kialakulni, ha motiváltak az órák látogatására, aminek az órák élvezhetôsége a kulcsa.

Kérdés ugyanakkor, hogy a select group videók megjelenése mennyire változtatja meg a hip-hop órák célját és tartalmát. Fuhrer (2017) szerint, a közösségi média előtti időkben más cél vezette a hip-hop órákat, és ezáltal a maitól eltérő volt az oktatás is. Fuhrer utal Ian Eastwood 2010-es, hip-hop órán felvett videójára. A felvételen az aznapi koreográfiát táncolják a tanítványok egy kisebb csoportban az óra végén. A táncosok nincsenek divatosan kiöltözve vagy körülvéve a már megszokott üdvrivalgó, félkörben álló többi résztvevővel. A felvételen a külön rögzített táncok összevágásán kívül nincsen szerkesztés (például belassítás slow-motion-ben vagy számítógépes fénycsóvák kirajzolódása a táncosok teste körül). A videót nem professzionális kamerával és filmessel rögzítették. Eastwood szerint ez a felvétel a hip-hop órák valódi célját mutatja be.

A szintén amerikai táncos és koreográfus Keone Madrid 2016-ban így nyilatkozott az órai videókról: „Már gyakran nem is tudom, hogy pár táncórai videó valóban óra vagy csak egy forgatás volt-e” (Fuhrer, 2017). Madrid szerint a táncosok fejlődését, ami egyben az óra legfontosabb célja lenne, nem szolgálja az, hogy az órák a videók elkészítésével telnek (Fuhrer, 2017). A megosztott tartalommal kapcsolatosan az amerikai táncos és koreográfus, Brian Puspos is kommentált, „(...) a fô ok arra, amiért már nem tanítok Los Angelesben. Az órát, amit tartok, már nem értékelnék és fogadnák el :(„, (Fuhrer, 2017). Puspos ezzel az órák tanítási menetére utalhatott, amit a közösségi média és a diákok új igényei sokaknál megváltoztattak. Börczi szerint ugyan vannak diákok, akik nem szeretik a videózást, de ez legfeljebb 3 ember a 60 főből. Hefler tapasztalatai szerint többen pedig csak azért járnak, hogy benne lehessenek az órai videókban.

Magyarországon hat éve jelent meg a videózás az órák keretein belül. Hefler úgy látja, egyre gyakoribb, és nincs is szinte olyan tanfolyami koreográfia, ami ne lenne felvéve. Mindenkinél kicsit változó, de Börczi körülbelül minden negyedik órán tart videózós órát. Az első három alkalom a koreográfia betanítására szolgál, és az ezutáni órán van mód arra, hogy a táncosok kisebb csoportokban is eltáncolhassák a teljes anyagot. Bőhm szerint a videózás lehetőséget ad a diákoknak, hogy a lehető legjobbat hozzák ki magukból. Hatalmas teljesítmény egyedül kiállni szólózni, ezért Börczi erre is próbálja biztatni a félénkebb táncosait. 


\section{Zimányi Gabriella | Lanszki Anita}

A HomeBros szerint a stílus autentikus ismerete az elsődleges, és nem egy koreográfia betanításán kell a hangsúlynak lennie. Ezért a videózás náluk inkább a freestyle-os, azaz improvizációs óráknál hasznos eszköz. Ezeket megörökítve a diákok elemezhetik és javíthatják mozdulataikat. Kljun is mindent ugyanúgy tanít, mint régen, csak most a kamera is megfigyelőként vesz részt az óráin. Az amerikai és angol táncórai profi filmesek segítsége lehetővé teszi, hogy a kamera megfigyelőként vehessen részt az órán. Tricia Miranda már 2014-ben saját filmest vett fel az óráinak rögzítésére (Hawgood, 2016). Magyarországon egyelőre még a tanárok vagy diákok filmezik egymást, ami Bőhm szerint nem probléma, mert egyre jobb eszközök készülnek kifejezetten mozgásfelvételre.

\subsection{A közösségimédia-használat hatása a táncos munkaerőpiacra}

\subsubsection{Szponzoráció}

Megkérdeztük az interjúalanyokat, hogy az online kevésbé követett tanároknak szükségük van-e fizetett reklámra és szponzorálásra ahhoz, hogy a tömegek elismerjék őket. A válaszok három részre oszlottak, és az amerikai, angol és magyar tánctanári munkák különbségeire is rávilágítottak.

Bőhm szerint a széleskörû́ elismertséghez nincs szüksége a kevésbé követett tanároknak fizetett reklámokra vagy szponzorálásra. Szerinte a nézőközönségnek elég megnéznie a feltöltött videókat, és ezáltal eldöntheti, hogy érték-e az, amit az adott tanár képvisel, vagy sem. Bőhm úgy véli, a nézőközönség értékelési preferenciája előre kikövetkeztethető. Ha a tanár kevésbé követett és nem a trendek szerint koreografál, akkor eleve felesleges számára a fizetett reklám vagy szponzorálás, mert az így terjeszthető tartalmak sem lennének népszerúek.

Ezzel szemben Hefler Dániel és Börczi Barbara úgy véli, hogy a kevésbé követett tanárok széleskörú elismertségét csak a fizetett reklámok és szponzorálások hozhatják meg. Hefler szerint hiába oszt meg egy kevésbé követett személy nagy mennyiségú tartalmat, láthatatlan marad a hirdetések nélkül. Börczi is éppen ezért gondolja úgy, hogy egy olyan kis országban, mint Magyarország mindenkinek fizetnie kell a közösségi platformokon, különben nem fog soha eljutni a tartalom a tömegekhez.

Kljun szerint ugyan segíthet a fizetett tartalom, de más lehetôségek is vannak a tömegek elismerésének megszerzésére. Szerinte minden tanárnak a saját döntése, hogy melyik utat választja. Vannak tanárok, akiknek a munkáit ugyan tömegek ismerik el, de az emberek nem ismerik névről a produkció megalkotóját vagy kivitelezőit. WilldaBeast szerepelt Black Eyed Peas videoklipben és táncolt Jason Derulo mögött is már az Upgrade U videója előtt. A táncos szakma csúcsán volt már ekkor is, de csak a 2013-as YouTube videója után ismerték meg a tömegek ôt személyesen is, mint táncost és alkotót (Burke, 2017).

A HomeBros szerint talán kezdő tanároknak lehet szüksége fizetett külső segítségre, mivel az online jelenlét fontos része a szakmának. Viszont a fiúk az OG-ket, a múfaj első Original Gangster úttörőit (Walsh, 2017) emlegették ellenpéldaként. Az OG-k idejében nem volt közösségi média, ezért amikor megjelentek a platformok, az új generáció táncosaihoz képest minimális követettségre tettek csak szert. De a HomeBros szerint ez nem számít, mert hiába van tízezer fő alatt a követőik száma, 


\section{Zimányi Gabriella | Lanszki Anita}

ha az önéletrajzukban a legelismertebb munkák szerepelnek. A nem OG hip-hop tanárok pedig a HomeBros szerint a kapcsolati rendszerük miatt nem szorulnak fizetett reklám segítségére. A tanárok Angliában és Amerikában személyesen ismerik az énekeseket és az ügynököket is. Lehet, hogy az utca emberei őket sem ismerik névről, de az általuk készített fellépésekért tömegek rajonganak.

Ez nagy eltérés a magyarországi tendenciákhoz képest. A budapesti hip-hop tanároknak nincs feltétlenül olyan kapcsolati rendszerük, ami a legjobb koreográfusi munkákat biztosítja számukra az országban. A magyar hip-hop táncos közösségben két csoport alakult ki. Az egyik a munkalehetőségeket biztosító és produkciókat koreografáló személyek csoportja, a másik pedig az aktívan órákat adó hip-hop tanárokból áll. Amerikában és Angliában is lehetôség van név nélküli, ám széleskörû́ elismertségre, például ha a tanár vagy a táncos részesévé válik egy adott produkciónak. A magyarországi tanároknak ez nem opció, mivel a zenei és egyéb előadói szakmák nem világhírúek így a produkciók sem jutnak el tömegekhez világszerte, ezért csak az Instagram-on való aktív részvétel vezethet ismertséghez.

\subsubsection{Munkalehetóségek}

A magyarországi tanárok úgy érzik, a közösségi média nincs semmilyen hatással a hip-hop táncosok munkalehetőségeire. Hefler szerint az itthoniak számára kevés az alternatíva és a castingok is ritkák, és ez a közösségi média kora előtt sem volt másként. A magas követettség talán csak a reklámforgatásoknál fontos, bár az Instagram-on népszerú hazai táncosokat Börczi szerint nem Magyarországról követik a legtöbben. Bőhm 70000 követójéból például csak nyolc százalék a magyarországi felhasználó. A magyar nem táncos közösség nem ismeri a népszerú hazai hip-hop táncosokat. Előfordult viszont, hogy az online közismert táncosokat negatív előítélet érte a munkaadók részéről. Bőhm elmesélte, hogy barátnőjével szemben munkaszituációban többször előfordult a negatív diszkrimináció pusztán azért, mert hatalmas online követettsége van. Börczi szerint a munkáltatók hibásan gondolhatják az online felkapott táncosokról, hogy beképzeltek.

Angliában és Amerikában egyértelmúen befolyásolja a közösségi média a táncosok munkalehetôségeit. Kljun úgy látja "(...) a mai világban a táncosoknak az Instagram profiljuk önéletrajzként szolgálhat", és szerinte gyakori, hogy a sok követővel rendelkező táncosoknak több lehetőségük is adódik. A közösségi média óta a HomeBros szerint több a munkalehetôsége a külföldieknek is. A HomeBros úgy véli, „valakiből, aki csak órákra járt és otthon edzett, hirtelen koreográfus vagy tanár is lehet pár év leforgása alatt a közösségi média kínálta lehetőségek által".

A HomeBros úgy látja, már nem kell a legkiválóbbnak táncosnak lenni ahhoz, hogy valaki munkát kapjon, mert a nézettségi számok is biztosíthatnak számára lehetôségeket. WilldaBeast elmondta, hogy vannak olyan munkák, ahol a megrendelő kifejezetten az Instagram-on híres táncosokat akarja csak alkalmazni (Howard, 2018). Bőhm szerint aki ma a táncos szakmával szeretne foglalkozni, az kénytelen időt szánni az online láthatóságára, mert ez a szakma részévé vált. 


\section{Zimányi Gabriella I Lanszki Anita}

\section{KONKLÚZIÓ}

Megállapíthatjuk, hogy a magyarországi hip-hop közösséghez lassabban jutott el a közösségimédia-platformok használata, de az alkalmazások aktív használata óta Magyarország nem túnt semmiben sem elmaradottnak az angol fóvároshoz vagy Los Angeleshez képest. A magyar táncosoknak szükséglet, a külföldieknek viszont eszköz a közösségi média. A közösségi média előnyei a tanárok szempontjából a kapcsolatépítés, a külföldi táncosok könnyebb elérhetősége, a motiváció és a reklámozás lehetősége. Az elvárások, kötelező trendek követése, a népszerûség hajszolása, a hamis értékrendek, a felgyorsult munkatempó és az érzelmi nyomások a közösségi média hátrányaihoz sorolhatóak. A hátrányok, úgy tûnik, csak a magyarországi tanárokat érintették.

A diákok szempontjából a közösségi média előnyei közé sorolható az egészséges életmódra nevelés, a külföldi táncosok követhetősége, a táncos karrier segítése és a motiváció is. A közösségi média hátránya az egyéniség elveszítése, a hamis önkép és motiváció, az órák céljának helytelen megítélése, a rövidebb idejú koncentráció valamint a megörökítés kényszere. Az előnyök és a hátrányok vegyesen a magyar, angol és amerikai területeken is előfordulnak.

A hip-hop órákra való felkészülés Londonban és Los Angelesben változatlan, azonban Budapesten módosult a közösségi média megjelenése óta. A londoni és los angelesi tanárok úgy érzik, sikerült a közösségi média előtt tartott óra menetét megőrizni, miközben alkalmazkodtak az újdonságokhoz. Magyarországon változás jelent meg az órák folyamatában a közösségi média óta. Ezt magyarázhatja a hirtelen beáramló információ mennyiség is. Budapesten nem őshonos a hip-hop, ezért a közösségi média használata óta sokat haladt előre az itthoni oktatás, mivel a tanároknak könnyebb követni a külföldi trendeket.

A közösségi média hatása a táncosok munkalehetôségeire nézve eltérô. Magyarországon nincs nagyobb változás az állásokat illetően. Ellenben Angliában és Amerikában teljes mértékben megsokszorozta a táncosok munkalehetőségeit az Instagram és az ahhoz hasonló platformok. A szakmai tudást azonban nem feltétlenül helyezik előtérbe a kinti munkáltatók a közösségi média megjelenése óta.

\section{A KUTATÁS KORLÁTAI ÉS PERSPEKTÍVÁI}

A közösségi média körülbelül öt-hét éve befolyásolja aktívan a hip-hop táncosok mindennapjait. A kutatásban azonban olyan személyeket is meginterjúvoltunk, akik nem olyan rég óta tanítanak. Nagyobb rálátása lehet a változásokra azoknak, akik jóval az online platformok megjelenése előtt is tanítottak. A kutatás folytatásában törekedni fogunk arra, hogy Nika Kljunhoz és Börczi Barbarához hasonló korosztályú tanárokat interjúztassunk, hogy a hip-hop oktatásának átalakulását tágabb perspektívából vizsgálhassuk.

Az interjúk során a kutatást korlátozhatta a közremúködők személyes tapasztalata és ezáltal esetleges elfogultsága is. Az angliai és amerikai válaszok kifejtettségét ugyanakkor befolyásolhatta, hogy Londonból és Los Angelesből csak online, amíg Budapesten személyesen készíthettük el a mélyinterjúkat. 


\section{Zimányi Gabriella | Lanszki Anita}

Ami a közösségi média hip-hop oktatásra gyakorolt hatásának jövőjét illeti, a hat tanár eltérő véleményt fogalmazott meg. Kljun segédeszközként gondol a közösségimédia-alkalmazásokra, de ennek ellenére szerinte semmiképpen sem bírhatnak nagy jelentôséggel a táncosok hétköznapjaira. Bôhm szerint a közösségi média megváltoztatta a lehetôségeket, de ezek az alkalmazások egyik napról a másikra eltúnhetnek. Akár az is elképzelhető szerinte, hogy egy új trend veszi majd át a helyüket. A HomeBros szerint a közösségi platformok paradigmaként fognak fennmaradni a táncos társadalomban, amit egyesek követni fognak, míg mások továbbra is elutasítják majd annak megosztó hatásai miatt. Hefler és Börczi egyetértettek abban, hogy a közösségi média negatív hatásai már aligha fokozódhatnak Magyarországon.

Howard (2018) szerint, ami egyszer elvész, azt nehéz újrateremteni, ezért a kérdés az, hogy a táncos közösség képes-e felmérni a valódi értékeket és ezáltal kontrollálni, hogy mit hagy elveszni és mit ôriz meg. A közösségimédia-használat megteremtette azt a közeget a hip-hop táncosoknak, hogy egy sokszínú, kozmopolita kapcsolati hálóban mozogjanak, és a táncos világban egymás mellett dolgozhatnak különböző múfajból érkezett táncosok (Phillips, 2018). Az interjúk alapján viszont megállapíthatjuk, hogy a jövő táncosait vezetố és inspiráló tanárokon nagyobb a felelősség, mint eddig bármikor. A tánctanároknak tisztában kell lenniük a közösségi média hatásaival, nemcsak diákjaikra, hanem önmagukra nézve is, és ezek ismeretében kell fejleszteniük tanítványaikat, valamint tudatosan óvni őket a káros hatásoktól.

\section{Irodalomjegyzék}

Ahmad, I. (2018, April 27). The History of Social Media [Infographic]. socialmediatoday.com. https:// www.socialmediatoday.com/news/the-history-of-social-media-infographic-1/522285/

Aniftos, R. (2018, August 28). How 2018 Became the Year of the Dance Challenge. billboard.com 20https: / / www.billboard.com/articles/news / 8472717/2018year-of-the-dance-challenge

Boyd, D. M., \& Ellison, N. B. (2007). Social Network Sites: Definition, History and Scholarship. Journal of Computer Mediated Communication, 13(1), 210-230. https://doi.org/10.1111/j.1083-6101.2007.00393.x

Burke, S. (2017, August 18). WilldaBeast, and Other Forces to Be Reckoned With. New York Times. https:/ / www.nytimes.com/2017/08/18/arts/dance/willdabeast-buildabeast-convention-immabeast.html

Clement, J. (2020). Global social networks ranked by number of users 2020. statista. com. https: / / www.statista.com/ statistics / 272014/ global-social-networks-ranked-by-number-of-users / \#statisticContainer on 5 Juni 2020.

Delgado, M. (2018). Music, Song, Dance, and Theatre. Broadway meets Social Justice Youth Community Practice. Oxford University Press.

Dickey, M. R. (2013, February 15). The 22 Key Turning Points In The History Of YouTube. Business Insider. https://www.businessinsider.com/key-turning-points-history-of-youtube-2013-2

Facebook Q1 Results (2020). https: / / edge.media-server.com/mmc/p/fx4dahch 


\section{Zimányi Gabriella | Lanszki Anita}

Fuhrer, M. (2017, Dec 6). Ian Eastwood Started an Intense-and Important-Convo About Class Videos. Dance Spirit, www.dancespirit.com/ian-eastwood-class-videoconvo-2515401864.html

Hawgood, A. (2016, August 9). Dancing Her Way to Pop Stardom, Thanks to YouTube and Rihanna. New York Times. https:/ / www.nytimes.com/2016/08/11/ fashion / tricia-miranda-choreographer-youtube-rihanna.html

Hill, M. L., \& Petchauer, E. (Eds.). (2012). Schooling hip- hop: Expanding hip- hop based education across the curriculum. Teachers College Press.

Howard, T. R. (2018, July 16). Is Instagram Changing The Dance World's Value System?. Dance Magazine. https:/ / www.dancemagazine.com/instagram-dance-2585216791.html

Hudson, M. (2018, May 1). What is Social Media. thebalancesmb.com. https: / /www. thebalancesmb.com/what-is-social-media-2890301

Hurd, S. (2016). Balancing homework and Hollywood-the real life of dance parents. ESPN Inc. 2016.12.06. http:/ / www.espn.com/espnw/culture/feature/ article / 18124709/ balancing-homework-hollywood-real-life-dance-parents

Laos, R.R. (2019). Social Media and Its Effects in the Commercial Dance World [MA Thesis]. University of California, Irvine Dance Department. https: / / escholarship.org/content / qt6dj8x3wp/qt6dj8x3wp_noSplash_04ce7d15d583036cf1e989406757e5f6.pdf

Pew Research Center (2018, February 5). Social Media Fact Sheet. Internet \& Technology. pewinternet.org. https:// www.pewinternet.org/fact-sheet/social-media/

Phillips, L. (2018, August 10). Everybody get up! The dance crazes changing the world. The Guardian. https://www.theguardian.com/music/2018/aug/10/ everybody-get-up-the-dance-crazes-changing-the-world

Poore, M. (2013). Using Social Media in the Classroom. SAGE Publications; Thousand Oaks.

Porfilio, B., Gardner, L. M., \& Roychoudhury, D. (2013). Ending the 'war against youth': Social media and hip-hop culture as sites of resistance, transformation and (re) conceptualization. Journal for Critical Education Policy Studies, 11(4). http: / / jceps. com/ wp- content/ uploads/ PDFs/ 11- 4- 05.pdf

Smith, B. R. (2013, October 6). How Instagram Took Over The World In Just Three Years. The Daily Telegraph. https://www.telegraph.co.uk/technology / 10355980/ How-Instagram-took-over-the-world-in-just-three-years.html

Walsh, A. (2017, December 14). O.G. Original Gangster: Breakdown. hiphopgoldenage.com, 2017.12.14. https://hiphopgoldenage.com/o-g-original-gangster-breakdown/ 


\section{Videók}

KreativMndz (2018, November 6). FEFE Dance - Delaney Glazer Choreography | 6ix9ine, Nicki Minaj, Murda Beatz | @deeglazer x \#kmda. YouTube. https: / / www.youtube.com/watch?v=ii_7BjfjLUQ\&list=RDii_7BjfjLUQ\&start_radio $=1 \& \mathrm{t}=0$

Joe Ryan Show (2009, February 14). Kennis Class: Ciara „Walk on the Wall”. YouTube. https: / / www.youtube.com/watch?v=mjjxVlaYe3c

Stiff Lauren (n.d.). The Shiggy Show - In My Feelings Challenge - Do The Shiggy. YouTube. https: / / www.youtube.com/ watch?v=69LjA8NuEsw

WilldaBeast Adams (2013, February 18). WilldaBeast Adams, Beyonce: Upgrade $\mathrm{U} \mid$ Learn Tutorial on immaDance.TV. YouTube. https://www.youtube.com/ watch?v=d3y17D_K9Zw 